\title{
The Microalgae Biorefinery: A Perspective on the Current Status and Future Opportunities Using Genetic Modification
}

\author{
Gino Schiano di Visconte ${ }^{1,2}$, Andrew Spicer ${ }^{1}$, Christopher J. Chuck ${ }^{3}$ and Michael J. Allen ${ }^{2,4, * \mathbb{B}}$ \\ 1 Algenuity, Eden Laboratory, Broadmead Road, Stewartby MK43 9ND, UK; gs@algenuity.com (G.S.d.V.); \\ aps@algenuity.com (A.S.) \\ 2 College of Life and Environmental Sciences, University of Exeter, Streatham Campus, Exeter EX4 4QD, UK \\ 3 Department of Chemical Engineering, University of Bath, Bath BA2 7AY, UK; c.chuck@bath.ac.uk \\ 4 Plymouth Marine Laboratory (PML), Prospect Place, The Hoe, Plymouth PL1 3DH, UK \\ * Correspondence: mija@pml.ac.uk
}

Received: 4 September 2019; Accepted: 6 November 2019; Published: 9 November 2019

\begin{abstract}
There is clear scientific evidence that emissions of greenhouse gases (GHG), arising from fossil fuel combustion and land-use change as a result of human activities, are perturbing the Earth's climate. Microalgae-derived biofuels have been chased since the 1980s without success but, lately, a new biorefinery concept is receiving increasing attention. Here, we discuss the possible solutions to the many problems that make this process unrealised to date, considering also the possibility of including genetically modified (GM) organisms to improve the productivity and process economics. Currently, unless coupled to a service or higher value product production, biofuels derived from microalgae fail to achieve economic reality. However, provided sufficient development of new technologies, potentially including new or improved organisms to lower both production and processing costs, as well as looking at the utility of distributed versus centralised production models, algae biofuels could achieve an impact, off-setting our heavy reliance on petroleum-based liquid fuels.
\end{abstract}

Keywords: biorefinery; GMO; biofuels; microalgae; biotechnology

\section{Introduction}

The use of microalgal biomass as a source of bulk, commodity chemicals has been of great interest since 1980, when the crude oil price reached almost $\$ 125$ per barrel [1]. During the following decades, a plethora of companies invested heavily to explore the realities of microalgae-derived biofuels [2], initially claiming that the results were within near reach. In 2008, when the oil price reached its maximum of $\$ 163.80$ per barrel, despite giving hope to the entire field of research, the harsh reality of process economics failed to overcome the fundamental operational problems with productivity and production costs. Put simply, microalgal biomass productivity was not sufficient, the scales involved were too small and extraction, purification and processing costs were too high. Facing the brutal realities of capitalism, the majority of companies working in this domain went bankrupt or were re-positioned as producers of higher value algae-derived products, predominantly for use as foods, feeds, nutraceuticals, or cosmetics [2].

There are still a few companies working on biofuels derived from microalgae, but the stark reality is that the process will need to be coupled with the production of one or more additional market-need driven products in order to balance the economics. Indeed, it could be argued it would be a folly to put the lowest value product at the fore-front of the industrial process, and priority should rightly be given to maximising the economic returns on the higher (perceived) value compound(s), rather than the low value product to be burned for energy. Taking this line of reasoning to its logical conclusion, 
the mass scales often quoted that are required for a single biofuel product from microalgae, are thus moot and irrelevant. For example, the size of land that should be dedicated to microalgae cultivation for bio-oil production in order to produce enough necessary to satisfy USA demand alone, is estimated to be about 30 million acres, which is about the size of the State of Florida (1\% of US land) [3]. Barring the whimsical and unprecedented reallocation of terrestrial infrastructure and resources to cultivation of microalgae, smaller production facilities (land or ocean based) are likely to be favoured, with the outputs of significantly higher value than liquid fuels. Most biofuels produced by the process are likely to be consumed by the process itself or used to run the plant (running pumps, heating, cooling, etc.) in a circular energy economy, rather than sold as a product.

Alternately, a distributed model of production where biomass is used to produce fuels potentially for use within a local defined radius to power, for instance, municipal vehicles, is coupled to the production of a higher perceived need resource or environmental remediation service, such as nutrient remediation or cleaning water, could lead to an economically favourable operation. Under the latter scenario, any fuel that is generated from the growth of microalgae produced as a result of nitrate and phosphate remediation acts as added value against the operational efficiency of cleaner water production [4].

The process of fractionating products from biomass for different applications is called a biorefinery. A biorefinery is "the sustainable processing of biomass into a spectrum of bio-based products (food, feed, chemicals, materials) and bioenergy (biofuels, power and/or heat)" [5]. While a microalgae biorefinery will take its inspiration from the crude oil refineries where every fraction is used predominantly for fuel-based products [6], the emphasis can never be on simply oxidising carbon chains to release energy but, rather, exploiting the complex organic compounds generated for their metabolic properties. The microalgae biorefinery will be about extracting value from bioactive proteins, carbohydrates, lipids, pigments, and all the other diverse metabolites produced by microalgae during real time growth (Figure 1), in contrast to the geological timescales relied on by unsustainable crude oil refineries to generate their 'crude' fuel products.

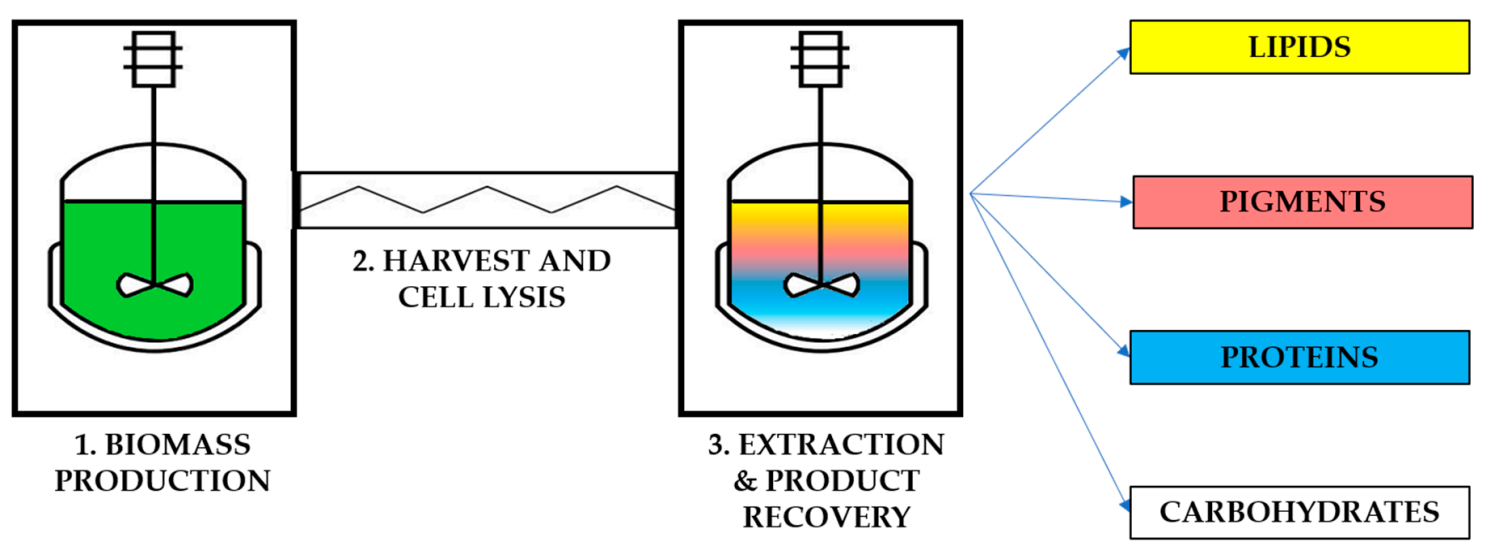

Figure 1. Schematic representation of a typical 'microalgae biorefinery'. The first step involves biomass production, once the desired concentration of biomass is achieved, the algae need to be de-watered and lysed in order to work on a smaller volume and release the molecules of interest, in the final step, the different components have to be extracted and purified.

A microalgae-based industrial process can be broadly catalogued into one of two types. The first type is high volume-low value that includes biofuels, $\mathrm{CO}_{2}$ bioremediation, wastewater treatment. The second type is low volume-high value consisting of nutraceutical, cosmeceutical, and pharmaceutical applications. Perhaps, the best application would be to couple the two scales of process with the same organism, combined infrastructure and with a biorefinery concept to produce high value compounds in a high-volume process. However, high volumes of high value biological products simply cause market saturation over time and, as the law of supply and demand dictates, leads to a lower market 
value. Unlike diamonds, biological compounds have a very definite shelf-life; they cannot be stored and released into the market if and when required. Further problems are the major discrepancies between the quality control and regulatory requirements for e.g. pharmaceutical production and that required for waste water treatment, bioremediation, or even feedstock generation. For these reasons, coupling the two scales of activity may not prove to be a realistic option.

The reality of developing a microalgae biorefinery is thus clear: undertake extensive technoeconomic assessment and identify your product(s), identify the scale of operation required, and only then build your bespoke infrastructure to match. The last few decades have been littered with examples of this process but, unfortunately, in reverse by which point it is often too late to save investors' money [2,7-9].

Yet, despite the errors of the past, a microalgae-inspired greener future is still a viable proposition. As the early biofuel advocates depart the arena, space is emerging for intelligent and measured activity while, in tandem, biotechnological advances are providing new and diverse commercial opportunities. The fundamental advantages of microalgae-based processes that triggered the initial industrial interest remain unchanged. Microalgae grow utilising nitrogen, phosphates, and trace elements, whilst fixing $\mathrm{CO}_{2}$ using the energy harnessed from light. These characteristics alone make them good candidates for wastewater treatment and industrial $\mathrm{CO}_{2}$ bioremediation. Yet, added to this, the metabolic diversity and physiological versatility of microalgae ensures that the biomass generated from their growth may also have further intrinsic value in addition to the remediation services they can undertake during growth. Thus, coupling these 'service value' processes with the biorefinery concept ('Biorefinery ${ }^{+}$') may enable new possibilities to change the way we view environmental pollution, turning problems into sustainable economic opportunities [10].

\section{Strain Selection}

Perhaps the key fundamental issue for any microalgae biorefinery is strain selection. Polycultures will inevitably give rise to lower value products; whereas monoculture, and the control over product quality that comes with it, will tend towards higher value products. A further advantage of monocultures is the ability to undertake extensive environmental optimisation for increased productivity and performance. In recent years, with the advent of genomic technologies, genetic manipulation has redefined the metabolic potential of microalgae by offering the ability to enhance existing, and even insert entirely new, strain properties [11]. Traditionally, bioprospecting was undertaken in oceans, ponds, rivers, and other aquatic reservoirs of interest to identify strains displaying desired characteristics - such as fast growth rate, robust growth, cheap/easy selection, metabolites of interest, etc. [12-14] —-which were subsequently incorporated into industrial processes. Building upon this, random chemical mutagenesis was utilised on the variants of what have now become well established strains, in order to improve their productivity for one particular metabolite of interest or one improved trait $[15,16]$ and provide 'proprietary status', often to appease nervous investors. The results of laboratory scale exploits to optimise the induction of particular metabolites are often willfully extrapolated, but rarely achieved at commercial scale, especially over seasonal dynamics. Targeted genetic modification does, however, circumvent or mitigate against many of these problems, improving productivity by direct design or producing entirely new compounds or recombinant proteins with higher value $[17,18]$.

Yet, the challenges of microalgal growth remain: effective scale-up and processing in an economically viable way. It is no surprise that the bold claims made by some biologists regarding the production potential of their microalgal strains can perhaps only be matched by their equivalent engineering counterparts with their usually unsubstantiated claims (hidden behind a mask of protecting their intellectual property) that their latest iteration of an established and well-understood cultivation technology holds the key to productivity for every algae, for every process, in every location. The truth is actually quite straight-forward and simple: for a successful industrial process, the right biological platform will need to be integrated with the right engineering infrastructure in a bespoke manner 
determined by local environmental conditions, infrastructures, market demands, and budgets. For a microalgae biorefinery to be successful, all these factors will need to be considered from the outset. Thus, a paradox exists: while genetic modification offers a road to success for a biorefinery, the developmental costs involved may actually limit the options available to how a particular microalgae process could be industrialised and, thus, impede exploitation efforts. A narrow focus on a particular product (i.e., not a biorefinery with multiple products per se) may be advantageous only if it is of sufficient value. Multifunctionalisation perhaps offers the most interesting opportunity in this regard and is gaining increasing traction and interest $[18,19]$, providing multiple higher value products simultaneously and moving closer towards the successful refinery model of the oil industry. It is clear that the successful application of a biorefinery model requires significant thought and consideration prior to expenditure.

Surprisingly, few microalgae strains are currently grown at commercially relevant industrial scale (Table 1). Arguably the greatest commercial successes are: Haematococcus pluvialis for production of the red pigment and potent antioxidant, astaxanthin; Dunaliella salina or bardawil for $\beta$-carotene; the cyanobacteria Arthrospira platensis or maxima (known as Spirulina sp.) for phycocyanin and biomass for food applications; Chlorella vulgaris for food applications and more [20]; the cyanobacteria Aphanizomenon flos-aquae for the curative properties of its extract [6]; Phaeodactylum tricornutum for production of fucoxanthin and eicosapentaenoic acid (EPA) rich oil [21]; Euglena gracilis for protein, lipids, vitamins and beta-1,3-glucan [22]; Nannochloropsis sp. for biomass, aquaculture, and EPA; Porphyridium cruentum for exopolysaccharides production; and Isochrysis sp. for aquaculture. In some cases, the industrial enterprises producing the biomass are not easy to identify due to not publicising their products openly, but instead marketing directly to multinational food/feed factories without disclosing the microalgae strains they are working with. However, the market is moving towards an expectation of greater transparency pushing such companies to share more information about the provenance of their products.

Table 1. Selection of microalgae companies producing biomass.

\begin{tabular}{|c|c|c|}
\hline Microalgae Strain & Main Product & Companies Involved in Biomass Production \\
\hline Aphanizomenon flos-aquae & Extract & Naturally-harvested [23] \\
\hline Arthrospira platensis/maxima & Phycocyanin & $\begin{array}{l}\text { Algaetech international [24], Cyanotech [25], DIC } \\
\text { Corporation [26], Olivier MicroAlgues [27], Parry } \\
\text { Nutraceuticals [28], Scotbio [29], Spira [30] }\end{array}$ \\
\hline Chlorella vulgaris & Biomass & $\begin{array}{l}\text { Allmicroalgae [31], Parry Nutraceuticals [28], } \\
\text { Roquette [32], Taiwan Chlorella Manufacturing } \\
\text { Company [33] }\end{array}$ \\
\hline Dunaliella salina/bardawil & Beta carotene & $\begin{array}{l}\text { InterClinical Laboratories [34], Monzonbiotech [35] } \\
\text { Nature Beta Technologies [36] }\end{array}$ \\
\hline Euglena gracilis & Beta-1,3-glucan & Algatech [22], Euglena Co [37] \\
\hline Haematococcus pluvialis & Astaxanthin & $\begin{array}{l}\text { AlgaeCan Biotech [38], Algaetech } \\
\text { International [24], Algalif [39], Algamo [40], } \\
\text { Algatech [21], AstaReal [41], Cyanotech [25], } \\
\text { Heliae [42], Yunnan Gingko Asta Biotech [43] }\end{array}$ \\
\hline Isochrysis sp. & Biomass & Archimede ricerche [44], Necton [45] \\
\hline Nannochloropsis sp. & EPA & $\begin{array}{l}\text { Algaspring [46], Algatech [21], } \\
\text { Allmicroalgae [31], Archimede ricerche [44], } \\
\text { Monzonbiotech [35], Necton [45] }\end{array}$ \\
\hline Phaeodactylum tricornutum & Fucoxanthin & Algatech [21], Necton [45] \\
\hline Porphyridium cruentum & Exopolysaccharides & Algatech [21], Necton [45] \\
\hline
\end{tabular}

The main properties that have led to the establishment and selection of these strains are: fast, reliable and robust growth under variable conditions; the ability to use a selective environment to 
maintain culture stability (e.g., Arthrospira platensis grows well in high $\mathrm{pH}$ medium which makes it easy to grow in open ponds with limited bacterial contamination); the composition of the biomass (high in lipids or protein or carbohydrate); the production of specific high value compounds (astaxanthin); physical and physiological robustness; susceptibility of the cells to lysis/desiccation/storage; resistance to predation. Crucially, many of the strains listed in Table 1 can now be genetically modified or are in the process of having protocols developed [47-55].

For fuel production, which has arguably dominated industrial-related microalgae research over the last couple of decades, the composition of fatty acids has always been deemed important, both quality and quantity. Microalgae provide a high proportion of unsaturated fatty acids (predominantly polar membrane lipids) and a significant content of saturated palmitic acid (C16:0; 17-40\%). Among the undesirable unsaturated fatty acids, European Standard EN 14,214 (2004) specifies a limit of 12\% for linolenic (C18:3) and 1\% for polyunsaturated ( $\geq 4$ double bonds) contents for quality biodiesel. Not all of the oils extracted from microalgae have linolenic and polyunsaturated fatty acid contents within specifications [56], so oil fractionation is a crucial aspect for production of quality biofuels, and may also be required to exploit the potential of unsaturated fatty acids in food and feed applications.

\section{Microalgae Genetic Engineering Methods}

Knowledge of the genome of the microalgae of interest facilitates the genetic engineering process. Initially, microalgal genetic engineering was based on the Chlamydomonas reinhardtii, the very first microalgae to have its genome sequenced [57]. This strain has been used as a model organism for developing most of the tools available at the moment. With the evolution of next generation sequencing technologies and the associated affordability, many strains have since been sequenced. Furthermore, transcriptomic analysis has become just as accessible enabling the possibility to find, e.g., inducible promoters, controlling elements, and other powerful tools.

Various protocols have been developed to insert foreign DNA in to microalgae. The most common ones are biolistic, glass beads, electroporation, and Agrobacterium-mediated transformations [58]. These protocols have been adapted mainly from plants' applications due to a similar cell wall characteristics. One of the problems faced after transformation is genetic stability. Most microalgae have tools to recognize foreign DNA, and degrade/silence it, supposedly to protect themselves from viral infections, transposable elements, or transgenes [59-61]. Insertion of specific introns in foreign genes can circumvent such problems by enhancing expression levels and gene stability [62]. Chloroplast transformation protocols (and the associated higher copy number this provides following homoplasmy) have been developed in order to improve expression of particular genes or produce specific molecules whose precursors are in this organelle. With the development of new genetic engineering tools, an exogenous chloroplast genome has been created in order to deal with complex sequence manipulation [63].

Directed gene editing is developing in microalgae as well. The CRISPR-Cas9 system enables scar-free gene modification and can be used to better understand the phenotype after knockout of specific genes or to improve the production of specific molecules blocking competitive pathways $[64,65]$. It is worthy of mention that, despite recent advances, genetic engineering in microalgae is behind in comparison to bacteria and yeast. This is for a variety of reasons including a relatively recent start of the research field, fewer interested researchers, and doubling times (and therefore selection times) are typically much longer. Furthermore, the focus in microalgae has been on developing commercially relevant industrial platforms in addition to model organisms, in order to exploit market opportunities faster, thereby diluting developmental efforts over a range of organisms.

\section{Societal Implications of GM}

Harvesting light from the sun and converting $\mathrm{CO}_{2}$ into organic biomass, algae are naturally and rightly viewed as having strong green credentials. The genetic modification or manipulation of microalgae potentially undermines this viewpoint and could potentially harm one of their strongest 
and unique selling points. Unlike terrestrial crops, microalgae cannot merely be plucked from the earth in their entirety and destroyed if deemed problematic. Mass cultivation of microalgae will inevitably lead to the low-level release of these microscopic organisms, which have the potential to survive in the natural environment away from the site of controlled industrial cultivation. For natural strains, this is unlikely to cause environmental harm. However, this may not automatically apply to genetically modified microalgae, depending on the manipulation involved. The phrase 'genetically-modified' and its associated acronym, 'GM' has mostly been recognised as negative based upon public opinion. This is primarily due to a lack of understanding of the underlying technology, but also to the large volume of negative press that is propagated within the context of exploitative large corporations who pushed the development and rollout of GM crops largely for corporate economic gain.

The primary drawback of the application of GM technologies to microalgae are the high costs associated with strain development (strain transformation and selection, stability of the strain and strain banking, toxicity testing); contained production and downstream processing; regulatory affairs and biosafety including the possible requirement for registration and monitoring. Should a GM microalga be cultivated at scale in open pond systems (by far the most commonly used cultivation method, see below) essentially, for all intents and purposes, the organism is being released into the environment. Microalgae cannot be made sterile to allow industry-controlled distribution like with GM plant varieties, even utilising different ways to control their growth, such as auxotrophy. Furthermore, the intellectual property protection of strains that can potentially go airborne and be 'isolated naturally' from surrounding sites poses a very real and serious commercial risk. Ironically, it is this commercial risk to industrial entities that may delay, limit, or even prevent large scale deployment of GM microalgae processes, rather than concerns over environmental damage or loss of biodiversity. Smaller scale operations in closed system photobioreactors offer the tight control over release desired, but limit production capacity and therefore the nature of the biorefinery. On the other hand, the major positive impact of applying GM technologies to improve or develop commercial microalgal strains is the enhanced overall economics due to the production of new high value molecules or improved growth or bioprocess efficiency, or a combination of all of these. Provided the returns are sufficient, phototrophic GM microalgae can offer a game changing scenario to process economics. As discussed previously, cultivating them at an appropriate scale and protecting commercial and environmental interests is of crucial importance.

In this regard, the regulations surrounding GM microalgae is having to evolve rapidly. At the moment, organisms generated by gene editing, including changes in native genes, are considered GM within the EU. The only modifications that are not considered GM are mutagenesis (chemical or UV radiation) and breeding, when possible. However, recent developments associated with the CRISPR/Cas and RNAi techniques threaten to introduce a regulatory gap to which the scientific community has yet to respond fully [66].

\section{Cultivation Systems}

Phototrophic microalgal cultivation systems can generally be classified into one of two classes, closed (for instance vertical or horizontal tubular, flat panel or other photobioreactor [PBR]) or open (for instance, open ponds, paddle-wheel driven raceways, and cascade raceways). Open ponds or raceways are used mainly for wastewater treatment or food and feed production because they are generally cheaper to set-up (capital expenditure-CAPEX) and run (operating expenditure-OPEX), but offer limited control over light, temperature, and $\mathrm{CO}_{2}$ conditions; the biomass is prone to external contamination or crashes due to predation and is not suitable for pharmaceutical applications. Closed PBRs offer improved culture stability and biomass densities and overall lower chances for contamination, but they have higher CAPEX and OPEX. Due to the generally considered requirement for contained cultivation, closed systems are the de facto systems of choice for GM microalga at present.

The open culturing systems in use at the moment at large scales produce low density cultures $(0.8-3.6 \mathrm{~g} / \mathrm{L})[67]$ and one of the main limiting factors in autotrophic growth is the light penetration 
into the culture [68]. Despite the obvious commercial risks discussed previously, academic interest has, nevertheless, focused on improving photosynthetic efficiencies by a range of approaches including GM to manipulate the light harvesting complex (typically via a decrease in antenna size) in order to increase the culture density [69-71]. To date the improvements have been low, and more effective results have simply been achieved by improvements to the cultivation systems such as simply increased mixing or decreasing the depth of the culture and thereby increasing the relative surface area used for cultivation [72].

Cascade raceways are a more recently developed innovation in open production systems [72], where the system design creates a shallow moving flow of culture maintaining an extremely small light path length and achieving substantially higher biomass densities (e.g., 15-35 g/L of Chlorella spp. has been reported [73]). Compared with tubular PBRs, flat panel PBRs seem to be the most productive choice for closed cultivation ( $24 \mathrm{~g} / \mathrm{L}$ of biomass (Chlorella sorokiniana)). However these systems suffer from very high costs and problems with scale up [74]. A new closed system in course of evaluation is the foam-bed PBR, where the algae are trapped in bubbles with a foaming agent and bovine serum albumin suspension to stabilise them; lower gas pressure is needed for mixing but the addition of a foam-breaking system is required so that overall operating costs are potentially higher and the yields are not specified as yet [75].

For all of the above production scenarios, results are still a far cry from heterotrophic production systems that can be used to produce some microalgal strains at industrial scales, where biomass densities of $100 \mathrm{~g} / \mathrm{L}$ and above dry weight can be achieved, at which point the biomass does not need to be dewatered but can just be dried, disrupted, or extracted, eliminating one energy intensive step of the downstream process.

\section{Harvesting Methods}

Microalgae harvesting is one of the most challenging aspects of the biorefinery process when applied at industrial scale owing to the high operational costs, which is estimated to be approximately $20-30 \%$ of the total downstream processing costs [76].

It is critical to choose the most appropriate harvesting method to apply, dependent on the strain and the culturing conditions, as well as the intended use for the biomass and any derived products. It is important to bear in mind that harvesting microalgae is often a case of removing a lot of water from a small amount of suspended biomass-as such, an increase in the culture density lowers the overall harvesting cost per biomass unit volume. Various approaches can be explored and applied to increase relative biomass densities and lower costs.

Flocculation is a low-cost way to concentrate biomass before centrifugation [77]. However, residues of the flocculant can be found in the harvested biomass and in the spent medium, which can pose a significant problem for commercial application [78]. Magnetic nanoparticles $\left(\mathrm{Fe}_{2} \mathrm{O}_{3}\right)$ have been explored for harvesting microalgae. These particles adsorb on the outside of the cells and seem to work better with a cationic polymer coating, improving the adsorption on the negatively charged microalgal cell surface. Through application of a magnetic field, both flocculation and separation from the medium can be achieved in one step and the nanoparticles can be recovered and reused after harvesting [77]. Genetic manipulation of Chlamydomonas has been used to create magnetic cells through overexpression of the iron binding protein ferritin in the chloroplast that, combined with high iron level in the medium right before harvesting, permitted magnetic separation of the biomass, facilitating lower energy cost dewatering [79].

Filtration methods can also be applied to concentrate biomass or products that have been secreted into the growth media. Micro- or dia-filtration is seen as an expensive alternative to flocculation. New tangential flow filtration (TFF) methods are under development in an effort to use less energy and decrease the time needed for filtration. For instance, the energy consumption necessary to dewater a culture of Chlorella minutissima using TFF to achieve a biomass density of up to $220 \mathrm{~g} / \mathrm{L}$ (coupling with centrifugation) was less than $1 \mathrm{kWh} / \mathrm{kg}_{\mathrm{DW}}$ [80]. 


\section{Cellular Disruption}

The successful extraction of multiple products in a biorefinery will usually rely upon cellular disruption to begin the isolation/fractionation of components of interest. To this end, cell disruption is often a vital step and can be broadly classified in four different approaches: mechanical, physical, biochemical, and biological. It should be stressed that these four approaches are not mutually exclusive, with some downstream processes combining different disruption methods to achieve the best result.

Mechanical approaches include bead milling and high-pressure homogenization. These are low temperature and neutral $\mathrm{pH}$ methods with mild conditions tending to preserve protein bioactivities [81]. The processes, however, tend to be energy expensive and create a dispersion of cell debris that can complicate the purification of the different fractions [82].

Physical cell disruption approaches include pulsed electric field (PEF) or ultrasound treatment (UT) as well as microwave treatment. PEF is a low shear and low temperature method; it generally has low efficiency on microalgae because of the common presence of a complex, often rigid or even elastic cell wall that protects them from lysis [83]. UT confers high shear stress and can be performed at low operating temperatures, but the cost to control the temperature of the biomass during processing is significant. This disruption method can prove problematic for applications within a biorefinery approach due to degradation of the water soluble components [84].

Enzyme digestion and alkali/acid treatments represent alternate biochemical approaches to break microalgal cells. Alkali/acid treatments are disruptive methods that, unfortunately, can degrade valuable components. Enzyme digestion is helpful for cell wall weakening and/or degradation, but is generally an expensive approach especially when applied at industrial scale. For a full digestion, proteases can be included to improve efficacy but, if used, protein components can also become degraded in this process. A mix of different degradation enzymes (sulfatase, chitinase, and lysozyme) can increase the permeability of some microalgal cell walls [85] and if coupled with PEF, the approach can be effective [83].

Biological disruption can be achieved for certain microalgal strains for which a virus has been described. The Chlorella variabilis strain NC64A that has been evaluated for production of high value molecules and biofuels is infected naturally by members of the Paramecium bursaria Chlorella Virus 1 (PBCV-1) family. Post-lysis, the lipid composition does not seem to be significantly different and the extraction yield is similar to the one achieved with ultrasonic disruption [86]; more studies are needed in terms of the protein composition of Chlorella variabilis biomass before and after infection and lysis. Furthermore, after infection with some virus strains, the cells start producing hyaluronan (HA), that could potentially increase the economics of the overall process if the yield of HA was optimised. An interesting aspect of utilising viruses to trigger cellular lysis is that the lytic process itself creates more viruses, which can be utilised for the lysis of the next batch, and so on, aiding process economics by self-generating the lytic agent, albeit potentially at the cost of reducing yields of the current harvest and adding a biological control challenge with regard to managing the production site operationally.

\section{Extraction}

Unless a specific high value molecule is produced by the microalgae, the most valuable compounds present are carbohydrates, proteins, pigments and oils (sterols, fatty acids). In a first step, the polar and non-polar compounds often need to be separated, most typically using organic solvents [87]. This will affect the quality of the proteins [88]. In a second step, components of the two fractions can be purified using HPLC methods.

Drying the biomass prior to lipid extraction increases the yield [89] but adds an additional step to the process, thereby increasing the energy costs. This step can be avoided using amines or amidines as solvents and, by adding $\mathrm{CO}_{2}$ into the solution, it is possible to switch the polarity of these helping also with the recovery of the solvent [90].

In a biorefinery approach, the various components of the biomass need to be extracted while avoiding damage to other components. Some products are more delicate compared to others and 
cascade extractions are often necessary. Yield, stability, and value are key drivers for the cascade order; it is typical for polar components to be extracted first. For this type of application, aqueous two-phase systems [91] and ionic liquids [92] are under evaluation.

In order to approach the biorefinery concept fully, biomass valorisation needs to be tackled as a whole process to be optimised instead of a multistep process, trying to couple together multiple steps where possible (e.g., cultivation/harvesting [93,94], harvesting/disruption [95,96], disruption/extraction $[97,98]$ ) but individual operational steps still need to be improved, optimized, and tested, prior to application on a larger scale within an understood techno-economic model.

The 'waste' biomass that remains after the extraction of the valuable compounds could still be used for production of gas, bio-oil, and biochar through the process of hydrothermal liquefaction (HTL) or pyrolysis. These two processes have been evaluated on multiple microalgae strains opting in favour of HTL [99]. HTL has also been tested on biomass derived from remediation of acid mine drainage (AMD). Results found that most of the contaminant metals were present within the solid waste and, as such, were easy to recover [10].

\section{Evaluating Biorefinery Model Scenarios}

There exist many published examples where evaluation of the application of a biorefinery approach has been undertaken for microalgae platforms $[100,101]$. Despite these publications on the theoretical algal biorefinery concept from academic groups, the experimental data supporting the theory is often poor and usually related to lab or small-scale experiments and is a long way, therefore, from being realised within any profitable industrial process. Lab-based techno-economic analysis of the processes would seem to support that the biorefinery approach can be profitable on an industrial scale, but this is yet to be convincingly proven.

There is clear scientific evidence that emissions of greenhouse gases (GHG), such as carbon dioxide $\left(\mathrm{CO}_{2}\right)$, methane $\left(\mathrm{CH}_{4}\right)$, and nitrous oxide $\left(\mathrm{N}_{2} \mathrm{O}\right)$, arising from fossil fuel combustion and land-use change as a result of human activities, are perturbing the Earth's climate [102]. Mitra and Mishra [100] have evaluated the feasibility to couple the biorefinery concept to wastewater treatment and $\mathrm{CO}_{2}$ remediation of flue gases in order to lower the production cost of the biomass. The resultant algae, as whole biomass, cannot be used for food and feed because it is effectively derived from waste treatment. The biomass can only be used after fractionation. In this way the purified valuable compounds like EPA and pigments can be used as feed ingredients after appropriate testing to establish the absence of biotic contaminants and heavy metals, while the residual 'waste' biomass can still be used for biogas production.

Zhang et al. [101] developed a protocol for the isolation of fucoxanthin (a brown-pigmented xanthophyll), eicosapentaenoic acid (omega-3 fatty acid), and chrysolaminarin (storage polysaccharide) from Phaeodactylum tricornutum biomass. In this case, no biomass disruption was adopted; a first step of ethanol extraction of the dry biomass (fucoxanthin partition), a second step of hexane extraction (EPA partition) and a final step of hydro-thermal acid extraction (chrysolaminarin) were performed with a purification step applied for each component. The process is complex and the extraction yield does not support application at large-scale. Furthermore, utilisation of hexane in the process creates a scenario where the EPA would not be useful in many of the highest value commercial applications. Again, this is an example of a nice academic study where many critical constraints that would kill the application within a real industrial context have not been carefully considered.

Production of biochar and bio-oil from Chlorella vulgaris biomass through pyrolysis for carbon sequestration was evaluated recently [103]. The products seem to be of good quality as alternative fuels, soil applications, and bio-adsorbent material but, disappointingly, a techno-economic analysis of the overall process is missing and this information is mission critical for industrial application.

Within a GM microalgal strain engineering context, as much as $0.2 \mathrm{~g}$ betulin (a high value compound of pharmaceutical interest) per kilogram of dry biomass could be produced from an engineered strain of Phaeodactylum tricornutum [17], alongside other natural compounds of mid-low 
value produced naturally by the organism. In engineered yeast (Saccharomyces cerevisae), $10 \mathrm{~g}$ of betulin can be extracted, about 50 times more, from an equivalent amount of produced biomass. Under the reported scenario, the calculated cost of biomass production was as much as 9 times higher for the Phaeodactylum platform versus the yeast, largely as a function of relative biomass densities. At the present time, for most phototrophic or mixotrophic microalgae cultivated using photosynthesis where a valuable compound can be produced, even a biorefinery approach will not be considered economically sufficient to compare the microalgal platform with another competitive production platform. Furthermore, the biorefinery approach under this scenario would not be considered sufficient to make the microalgal process profitable-the potential increased output of the biorefinery approach is negligible compared to the value of any high value compound that is produced.

One of the most promising fuel based biorefinery designs is the combined algal processing (CAP) platform designed by NREL. In this system microalgae are fractionated using a dilute acid pretreatment and then treated with commercial cellulases. This gives a sugar rich hydrolysate for fermentation, while making the lipid and protein fractions more available for extraction. The lipid is only extracted at the end of the process, after fermentation. This process has been demonstrated to produce 'green' diesel (from lipid fraction) and ethanol (from fermentation) at the same time. The techno-economic analysis showed that the cost of microalgal biofuel from this process was reduced by up to $\$ 0.95$ per gallon gasoline equivalent (GGE) over more traditional processing [104]. Recently, further iterations of this approach have demonstrated that succinic acid could also be produced and HTL applied to the residual biomass remaining at the end of the process to extract maximum energy yield overall [105].

$\mathrm{CAP}$ is potentially a key route to affordable biofuels and it offers a system that is extremely robust. This offers a lower risk system which can also use microalgae cultured in low sterility conditions, such as from raceway ponds. Invasive species, however, typically reduce yields; by not being reliant on lipid or specific sugars, contaminations only increase the carbohydrate fraction or the material that can be processed through HTL.

\section{Conclusions}

A biorefinery approach, at least on paper, looks like a great solution in order to improve the techno-economics of microalgae commercial applications, especially for high volume-low value processes (biofuels, $\mathrm{CO}_{2}$ bioremediation, wastewater treatment). The biorefinery approach attempts to increase the number of products or outputs, thereby improving the economics of the overall process by extracting maximum value. Indeed, there are companies actively working in this space (Valicor Renewables \& Nutraceuticals, for instance) although a formal convincing success story awaits. Successful application may also contribute to a positive impact on the climate emergency we are now facing, although substantial improvements still need to be achieved and convincingly demonstrated within a relevant industrial context in order for this to become a reality.

With regard to the production of a truly high value product (natural or GM) in microalgae, the biorefinery approach can become a costly distraction or obstacle to optimising the production process, harvesting, and the conditions needed to extract the primary product of interest. By attempting to co-optimise the production and/or extraction of secondary co-products the primary product upon which the process techno-economics must rely can end up reduced in yield and/or quality, reducing any benefit gained from the derived secondary products. At the present time and industrial climate, there is no convincing industrial-scale example of a biorefinery process involving microalgae. In practice, the primary product is extracted or produced and any residual material is disposed of through a variety of methods. This is perhaps how the first microalgal biorefinery will develop: from the opportunistic valorisation of existing wastes from current single-product based platforms. Hydrothermal liquefaction is developing as an obvious and useful technique for organic waste valorisation. The powerful, successful and lucrative biorefineries of the future, the ones that we all dream about in the present, will require greater thought and a holistic approach from the start. The wheel does not need to be entirely reinvented for microalgal biorefineries to become a reality; the size, shape and mechanism, as well as 
the economic drivers that power it, will dictate the pace of development, and ultimately their future commercial success.

Author Contributions: Conceptualization, M.J.A. and C.J.C.; Writing-original draft preparation, G.S.d.V.; Writing-review and editing, M.J.A., C.J.C. and A.S.; Supervision, A.S. and M.J.A.

Funding: We would like to thank the Biotechnology and Biological Sciences Research Council and Innovate-UK for support through grant BB/N010396/1 entitled "Pilot Algal Lipids Manufacturing in the UK (PALM-UK)".

Conflicts of Interest: At the time of the study, G.S.d.V. and A.S. were employed by Algenuity, a division of Spicer Consulting Limited, UK, that is also sponsoring the PhD studies of G.S.d.V.

\section{References}

1. Available online: https://www.macrotrends.net/1369/crude-oil-price-history-chart (accessed on 19 August 2019).

2. Available online: https://www.greentechmedia.com/articles/read/lessons-from-the-great-algae-biofuelbubble\#gs.4513sf (accessed on 19 September 2019).

3. Hannon, M.; Gimpel, J.; Tran, M.; Rasala, B.; Mayfield, S. Biofuels from algae: Challenges and potential. Biofuels 2010, 1, 763-784. [CrossRef] [PubMed]

4. Lundquist, T.J.; Woertz, I.C.; Quinn, N.W.T.; Benemann, J.R. Lawrence Berkeley National LaboratoryBerkeley, California. XRDS 2010, 17, 58.

5. Jungmeier, G.; Ree, R.V.; de Jong, E.; Stichnothe, H.; de Bari, I.; Wellisch, M.; Bell, G.; Spaeth, J.; Torr, K.; Kimura, S. The "Biorefinery Fact Sheet" and its Application to Wood Based Biorefining-Case Studies of IEA Bioenergy Task 42 "Biorefining”. Biorefining Circ. Econ. 2015, 1-6.

6. Hsu, C.S.; Robinson, P.R. Petroleum Science and Technology; Springer International Publishing: Cham, Switzerland, 2019; ISBN 978-3-030-16274-0.

7. Richmond, A. Microalgal biotechnology at the turn of the millennium: A personal view. J. Appl. Phycol. 2000, 12, 441-451. [CrossRef]

8. Biello, D. The False Promise of Biofuels. Sci. Am. 2011, 305, 58-65. [CrossRef]

9. Mascarelli, A.L. Gold rush for algae. Nature 2009, 461, 460-461. [CrossRef]

10. Raikova, S.; Smith-Baedorf, H.; Bransgrove, R.; Barlow, O.; Santomauro, F.; Wagner, J.L.; Allen, M.J.; Bryan, C.G.; Sapsford, D.; Chuck, C.J. Assessing hydrothermal liquefaction for the production of bio-oil and enhanced metal recovery from microalgae cultivated on acid mine drainage. Fuel Process. Technol. 2016, 142, 219-227. [CrossRef]

11. Singh, P.; Kumari, S.; Guldhe, A.; Misra, R.; Rawat, I.; Bux, F. Trends and novel strategies for enhancing lipid accumulation and quality in microalgae. Renew. Sustain. Energy Rev. 2016, 55, 1-16. [CrossRef]

12. de Vera, C.; Díaz Crespín, G.; Hernández Daranas, A.; Montalvão Looga, S.; Lillsunde, K.-E.; Tammela, P.; Perälä, M.; Hongisto, V.; Virtanen, J.; Rischer, H.; et al. Marine Microalgae: Promising Source for New Bioactive Compounds. Mar. Drugs 2018, 16, 317. [CrossRef]

13. Mutanda, T.; Ramesh, D.; Karthikeyan, S.; Kumari, S.; Anandraj, A.; Bux, F. Bioprospecting for hyper-lipid producing microalgal strains for sustainable biofuel production. Bioresour. Technol. 2011, 102, 57-70. [CrossRef]

14. Bohutskyi, P.; Liu, K.; Nasr, L.K.; Byers, N.; Rosenberg, J.N.; Oyler, G.A.; Betenbaugh, M.J.; Bouwer, E.J. Bioprospecting of microalgae for integrated biomass production and phytoremediation of unsterilized wastewater and anaerobic digestion centrate. Appl. Microbiol. Biotechnol. 2015, 99, 6139-6154. [CrossRef] [PubMed]

15. Tripathi, U.; Venkateshwaran, G.; Sarada, R.; Ravishankar, G.A. Studies on Haematococcus pluvialis for improved production of astaxanthin by mutagenesis. World J. Microbiol. Biotechnol. 2001, 17, 143-148. [CrossRef]

16. Hlavova, M.; Turoczy, Z.; Bisova, K. Improving microalgae for biotechnology—From genetics to synthetic biology. Biotechnol. Adv. 2015, 33, 1194-1203. [CrossRef] [PubMed]

17. D'Adamo, S.; Schiano di Visconte, G.; Lowe, G.; Szaub-Newton, J.; Beacham, T.; Landels, A.; Allen, M.J.; Spicer, A.; Matthijs, M. Engineering the unicellular alga Phaeodactylum tricornutum for high-value plant triterpenoid production. Plant Biotechnol. J. 2019, 17, 75-87. [CrossRef] 
18. Pudney, A.; Gandini, C.; Economou, C.K.; Smith, R.; Goddard, P.; Napier, J.A.; Spicer, A.; Sayanova, O. Multifunctionalizing the marine diatom Phaeodactylum tricornutum for sustainable co-production of omega-3 long chain polyunsaturated fatty acids and recombinant phytase. Sci. Rep. 2019, 9, 11444. [CrossRef]

19. 't Lam, G.P.; Vermuë, M.H.; Eppink, M.H.M.; Wijffels, R.H.; van den Berg, C. Multi-Product Microalgae Biorefineries: From Concept towards Reality. Trends Biotechnol. 2018, 36, 216-227. [CrossRef]

20. Available online: https://www.algenuity.com/algenuitys-chlorella-colours-platform-launches-at-this-yearsvitafoods-europe (accessed on 19 August 2019).

21. Available online: https://www.algatech.com/our-microalgae/?microalgae=79 (accessed on 19 August 2019).

22. Available online: https://www.nutritioninsight.com/news/algatech-to-launch-microalgae-derived-productsfrom-f3-platform-biologics.html?utm_source=ActiveCampaign\&utm_medium=email\&utm_content=8+ Aug+\%7C+Algatech+to+launch+microalgae+products+from+F3+Platform+Biologics+-+Consuming+ poultry+may+decrease+breast+cancer+risk+-+Olive+oil+linked+to+decreased+CVD+risk+-+Dixie+ Botanicals+launches+CBD+gummies\&utm_campaign=2019-08-08+NI+Daily+\%28Innova+promo\%29 (accessed on 19 August 2019).

23. Available online: https://www.nutrigea.com/it/klamath_world/klamath_world.aspx (accessed on 20 September 2019).

24. Available online: https://algaetech.com.my/ (accessed on 19 September 2019).

25. Available online: https://www.cyanotech.com/ (accessed on 19 September 2019).

26. Available online: http://www.dic-global.com/en/products/health_foods/ (accessed on 19 September 2019).

27. Available online: https://www.olivier-microalgues.fr/ (accessed on 19 September 2019).

28. Available online: http://www.parrynutraceuticals.com/Products (accessed on 19 September 2019).

29. Available online: https://scotbio.com/products (accessed on 19 September 2019).

30. Available online: https://spirainc.com/ (accessed on 19 September 2019).

31. Available online: https://ezone.vitafoods.eu.com/exhibitors/allmicroalgae (accessed on 19 September 2019).

32. Available online: https://www.roquette.com/animal-nutrition-microalgae (accessed on 19 September 2019).

33. Available online: http://www.taiwanchlorella.com/ (accessed on 19 September 2019).

34. Available online: http://www.interclinical.com.au/detail.php?algotene (accessed on 19 September 2019).

35. Available online: https://mznbiotech.com/products/ (accessed on 19 September 2019).

36. Available online: https://finder.startupnationcentral.org/company_page/nature-beta-technologies (accessed on 19 September 2019).

37. Available online: https://www.euglena.jp/ (accessed on 19 September 2019).

38. Available online: https://algaecan.com/ (accessed on 19 September 2019).

39. Available online: https://algalif.com/ (accessed on 19 September 2019).

40. Available online: http://www.algamo.cz/kontakt/ (accessed on 19 September 2019).

41. Available online: https://astareal.com/en/ (accessed on 19 September 2019).

42. Available online: https://heliaeglobal.com/ (accessed on 19 September 2019).

43. Available online: https://news.algaeworld.org/2015/07/the-worlds-largest-haematococcus-farm-in-china/ (accessed on 19 September 2019).

44. Available online: http://www.archimedericerche.com/en/about-us.html (accessed on 19 September 2019).

45. Available online: http://phytobloom.com/cosmetics/ (accessed on 19 September 2019).

46. Available online: https://www.algaspring.nl/company-information/ (accessed on 19 September 2019).

47. Toyomizu, M.; Suzuki, K.; Kawata, Y.; Kojima, H.; Akiba, Y. Effective transformation of the cyanobacterium Spirulina platensis using electroporation. J. Appl. Phycol. 2001, 13, 209-214. [CrossRef]

48. Cha, T.S.; Yee, W.; Aziz, A. Assessment of factors affecting Agrobacterium-mediated genetic transformation of the unicellular green alga, Chlorella vulgaris. World J. Microbiol. Biotechnol. 2012, 28, 1771-1779. [CrossRef]

49. Apt, K.E.; Grossman, A.R.; Kroth-Pancic, P.G. Stable nuclear transformation of the diatomPhaeodactylum tricornutum. Molec. Gen. Genet. 1996, 252, 572-579. [CrossRef]

50. Feng, S.; Xue, L.; Liu, H.; Lu, P. Improvement of efficiency of genetic transformation for Dunaliella salina by glass beads method. Mol. Biol. Rep. 2009, 36, 1433-1439. [CrossRef]

51. Doetsch, N.A.; Favreau, M.R.; Kuscuoglu, N.; Thompson, M.D.; Hallick, R.B. Chloroplast transformation in Euglena gracilis: Splicing of a group III twintron transcribed from a transgenic psbK operon. Curr. Genet. 2001, 39, 49-60. [CrossRef] [PubMed] 
52. Steinbrenner, J.; Sandmann, G. Transformation of the Green Alga Haematococcus pluvialis with a Phytoene Desaturase for Accelerated Astaxanthin Biosynthesis. Appl. Environ. Microbiol. 2006, 72, 7477-7484. [CrossRef] [PubMed]

53. Prasad, B.; Vadakedath, N.; Jeong, H.-J.; General, T.; Cho, M.-G.; Lein, W. Agrobacterium tumefaciens-mediated genetic transformation of haptophytes (Isochrysis species). Appl. Microbiol. Biotechnol. 2014, 98, 8629-8639. [CrossRef] [PubMed]

54. Vieler, A.; Wu, G.; Tsai, C.-H.; Bullard, B.; Cornish, A.J.; Harvey, C.; Reca, I.-B.; Thornburg, C.; Achawanantakun, R.; Buehl, C.J.; et al. Genome, Functional Gene Annotation, and Nuclear Transformation of the Heterokont Oleaginous Alga Nannochloropsis oceanica CCMP1779. PLoS Genet. 2012, 8, e1003064. [CrossRef] [PubMed]

55. Lapidot, M.; Raveh, D.; Sivan, A.; Arad, S.M.; Shapira, M. Stable Chloroplast Transformation of the Unicellular Red Alga Porphyridium Species. Plant Physiol. 2002, 129, 7-12. [CrossRef] [PubMed]

56. Gouveia, L.; Oliveira, A.C. Microalgae as a raw material for biofuels production. J. Ind. Microbiol. Biotechnol. 2009, 36, 269-274. [CrossRef]

57. Merchant, S.S.; Prochnik, S.E.; Vallon, O.; Harris, E.H.; Karpowicz, S.J.; Witman, G.B.; Terry, A.; Salamov, A.; Fritz-Laylin, L.K.; Marechal-Drouard, L.; et al. The Chlamydomonas Genome Reveals the Evolution of Key Animal and Plant Functions. Science 2007, 318, 245-250. [CrossRef]

58. León, R.; Fernández, E. Nuclear Transformation of Eukaryotic Microalgae. In Transgenic Microalgae as Green Cell Factories; León, R., Galván, A., Fernández, E., Eds.; Advances in Experimental Medicine and Biology; Springer: New York, NY, USA, 2007; pp. 1-11, ISBN 978-0-387-75532-8.

59. Cerutti, H.; Johnson, A.M.; Gillham, N.W.; Boynton, J.E. Epigenetic silencing of a foreign gene in nuclear transformants of Chlamydomonas. Plant Cell 1997, 9, 925-945. [CrossRef]

60. León-Bañares, R. Transgenic microalgae as green cell-factories. Trends Biotechnol. 2004, 22, 45-52. [CrossRef]

61. Wu-Scharf, D. Transgene and Transposon Silencing in Chlamydomonas reinhardtii by a DEAH-Box RNA Helicase. Science 2000, 290, 1159-1162. [CrossRef]

62. Lumbreras, V.; Stevens, D.R.; Purton, S. Efficient foreign gene expression in Chlamydomonas reinhardtii mediated by an endogenous intron: Foreign gene expression in Chlamydomonas. Plant J. 1998, 14, 441-447. [CrossRef]

63. O'Neill, B.M.; Mikkelson, K.L.; Gutierrez, N.M.; Cunningham, J.L.; Wolff, K.L.; Szyjka, S.J.; Yohn, C.B.; Redding, K.E.; Mendez, M.J. An exogenous chloroplast genome for complex sequence manipulation in algae. Nucleic Acids Res. 2012, 40, 2782-2792. [CrossRef] [PubMed]

64. Nomura, T.; Inoue, K.; Uehara-Yamaguchi, Y.; Yamada, K.; Iwata, O.; Suzuki, K.; Mochida, K. Highly efficient transgene-free targeted mutagenesis and single-stranded oligodeoxynucleotide-mediated precise knock-in in the industrial microalga Euglena gracilis using Cas9 ribonucleoproteins. Plant Biotechnol. J. 2019, 17, 2032-2034. [CrossRef] [PubMed]

65. Naduthodi, M.I.S.; Mohanraju, P.; Südfeld, C.; D'Adamo, S.; Barbosa, M.J.; van der Oost, J. CRISPR-Cas ribonucleoprotein mediated homology-directed repair for efficient targeted genome editing in microalgae Nannochloropsis oceanica IMET1. Biotechnol. Biofuels 2019, 12, 66. [CrossRef] [PubMed]

66. Spicer, A.; Molnar, A. Gene Editing of Microalgae: Scientific Progress and Regulatory Challenges in Europe. Biology 2018, 7, 21. [CrossRef]

67. Gifuni, I.; Pollio, A.; Safi, C.; Marzocchella, A.; Olivieri, G. Current Bottlenecks and Challenges of the Microalgal Biorefinery. Trends Biotechnol. 2019, 37, 242-252. [CrossRef] [PubMed]

68. de Vree, J.H.; Bosma, R.; Janssen, M.; Barbosa, M.J.; Wijffels, R.H. Comparison of four outdoor pilot-scale photobioreactors. Biotechnol. Biofuels 2015, 8, 215. [CrossRef]

69. Mussgnug, J.H.; Thomas-Hall, S.; Rupprecht, J.; Foo, A.; Klassen, V.; McDowall, A.; Schenk, P.M.; Kruse, O.; Hankamer, B. Engineering photosynthetic light capture: Impacts on improved solar energy to biomass conversion. Plant Biotechnol. J. 2007, 5, 802-814. [CrossRef]

70. de Mooij, T.; Janssen, M.; Cerezo-Chinarro, O.; Mussgnug, J.H.; Kruse, O.; Ballottari, M.; Bassi, R.; Bujaldon, S.; Wollman, F.-A.; Wijffels, R.H. Antenna size reduction as a strategy to increase biomass productivity: A great potential not yet realized. J. Appl. Phycol. 2015, 27, 1063-1077. [CrossRef]

71. Shin, W.-S.; Lee, B.; Jeong, B.; Chang, Y.K.; Kwon, J.-H. Truncated light-harvesting chlorophyll antenna size in Chlorella vulgaris improves biomass productivity. J. Appl. Phycol. 2016, 28, 3193-3202. [CrossRef] 
72. Doucha, J.; Lívanský, K. Productivity, CO2/O2 exchange and hydraulics in outdoor open high density microalgal (Chlorella sp.) photobioreactors operated in a Middle and Southern European climate. J. Appl. Phycol. 2006, 18, 811-826. [CrossRef]

73. Masojídek, J.; Torzillo, G. Mass Cultivation of Freshwater Microalgae. In Encyclopedia of Ecology; Jørgensen, S.E., Fath, B.D., Eds.; Academic Press: Oxford, UK, 2008; pp. 2226-2235, ISBN 978-0-08-045405-4.

74. Gifuni, I.; Pollio, A.; Marzocchella, A.; Olivieri, G. New ultra-flat photobioreactor for intensive microalgal production: The effect of light irradiance. Algal Res. 2018, 34, 134-142. [CrossRef]

75. Janoska, A.; Lamers, P.P.; Hamhuis, A.; van Eimeren, Y.; Wijffels, R.H.; Janssen, M. A liquid foam-bed photobioreactor for microalgae production. Chem. Eng. J. 2017, 313, 1206-1214. [CrossRef]

76. Mata, T.M.; Martins, A.A.; Caetano, N.S. Microalgae for biodiesel production and other applications: A review. Renew. Sustain. Energy Rev. 2010, 14, 217-232. [CrossRef]

77. Vandamme, D.; Foubert, I.; Muylaert, K. Flocculation as a low-cost method for harvesting microalgae for bulk biomass production. Trends Biotechnol. 2013, 31, 233-239. [CrossRef] [PubMed]

78. Eyley, S.; Vandamme, D.; Lama, S.; Van den Mooter, G.; Muylaert, K.; Thielemans, W. CO 2 controlled flocculation of microalgae using pH responsive cellulose nanocrystals. Nanoscale 2015, 7, 14413-14421. [CrossRef]

79. Sayre, R.; Postier, B. Modification of microalgae for magnetic properties. US Patent App. 13/808,746, 2013.

80. Gerardo, M.L.; Zanain, M.A.; Lovitt, R.W. Pilot-scale cross-flow microfiltration of Chlorella minutissima: A theoretical assessment of the operational parameters on energy consumption. Chem. Eng. J. 2015, 280, 505-513. [CrossRef]

81. Schwenzfeier, A.; Wierenga, P.A.; Gruppen, H. Isolation and characterization of soluble protein from the green microalgae Tetraselmis sp. Bioresour. Technol. 2011, 102, 9121-9127. [CrossRef]

82. Postma, P.R.; Suarez-Garcia, E.; Safi, C.; Yonathan, K.; Olivieri, G.; Barbosa, M.J.; Wijffels, R.H.; Eppink, M.H.M. Energy efficient bead milling of microalgae: Effect of bead size on disintegration and release of proteins and carbohydrates. Bioresour. Technol. 2017, 224, 670-679. [CrossRef]

83. 't Lam, G.P.; van der Kolk, J.A.; Chordia, A.; Vermuë, M.H.; Olivieri, G.; Eppink, M.H.M.; Wijffels, R.H. Mild and Selective Protein Release of Cell Wall Deficient Microalgae with Pulsed Electric Field. ACS Sustain. Chem. Eng. 2017, 5, 6046-6053. [CrossRef]

84. Adam, F.; Abert-Vian, M.; Peltier, G.; Chemat, F. “Solvent-free" ultrasound-assisted extraction of lipids from fresh microalgae cells: A green, clean and scalable process. Bioresour. Technol. 2012, 114, 457-465. [CrossRef] [PubMed]

85. Gerken, H.G.; Donohoe, B.; Knoshaug, E.P. Enzymatic cell wall degradation of Chlorella vulgaris and other microalgae for biofuels production. Planta 2013, 237, 239-253. [CrossRef] [PubMed]

86. Sun, Z.; Zhou, Z. Nature-inspired virus-assisted algal cell disruption for cost-effective biofuel production. Appl. Energy 2019, 251, 113330. [CrossRef]

87. Mubarak, M.; Shaija, A.; Suchithra, T.V. A review on the extraction of lipid from microalgae for biodiesel production. Algal Res. 2015, 7, 117-123. [CrossRef]

88. Mattos, C. Proteins in organic solvents. Curr. Opin. Struct. Biol. 2001, 11, 761-764. [CrossRef]

89. Williams, P.J.1.B.; Laurens, L.M.L. Microalgae as biodiesel \& biomass feedstocks: Review \& analysis of the biochemistry, energetics \& economics. Energy Environ. Sci. 2010, 3, 554.

90. Jessop, P.G.; Heldebrant, D.J.; Li, X.; Eckert, C.A.; Liotta, C.L. Reversible nonpolar-to-polar solvent. Nature 2005, 436, 1102. [CrossRef]

91. Suarez Ruiz, C.A.; Emmery, D.P.; Wijffels, R.H.; Eppink, M.H.; van den Berg, C. Selective and mild fractionation of microalgal proteins and pigments using aqueous two-phase systems: Selective and mild fractionation of microalgal. J. Chem. Technol. Biotechnol. 2018, 93, 2774-2783. [CrossRef]

92. Orr, V.C.A.; Rehmann, L. Ionic liquids for the fractionation of microalgae biomass. Curr. Opin. Green Sustain. Chem. 2016, 2, 22-27. [CrossRef]

93. Morrissey, K.L.; He, C.; Wong, M.H.; Zhao, X.; Chapman, R.Z.; Bender, S.L.; Prevatt, W.D.; Stoykovich, M.P. Charge-tunable polymers as reversible and recyclable flocculants for the dewatering of microalgae: Reversible and Recyclable Flocculants. Biotechnol. Bioeng. 2015, 112, 74-83. [CrossRef]

94. Zheng, Y.; Roberts, M.; Kelly, J.; Zhang, N.; Walker, T. Harvesting microalgae using the temperature-activated phase transition of thermoresponsive polymers. Algal Res. 2015, 11, 90-94. [CrossRef] 
95. Zheng, Y.; Xiao, R.; Roberts, M. Polymer-enhanced enzymatic microalgal cell disruption for lipid and sugar recovery. Algal Res. 2016, 14, 100-108. [CrossRef]

96. Kim, D.-Y.; Oh, Y.-K.; Park, J.-Y.; Kim, B.; Choi, S.-A.; Han, J.-I. An integrated process for microalgae harvesting and cell disruption by the use of ferric ions. Bioresour. Technol. 2015, 191, 469-474. [CrossRef]

97. Salam, K.A.; Velasquez-Orta, S.B.; Harvey, A.P. Kinetics of fast alkali reactive extraction/in situ transesterification of Chlorella vulgaris that identifies process conditions for a significant enhanced rate and water tolerance. Fuel Process. Technol. 2016, 144, 212-219. [CrossRef]

98. Salam, K.A.; Velasquez-Orta, S.B.; Harvey, A.P. A sustainable integrated in situ transesterification of microalgae for biodiesel production and associated co-product-a review. Renew. Sustain. Energy Rev. 2016, 65, 1179-1198. [CrossRef]

99. Chiaramonti, D.; Prussi, M.; Buffi, M.; Rizzo, A.M.; Pari, L. Review and experimental study on pyrolysis and hydrothermal liquefaction of microalgae for biofuel production. Appl. Energy 2017, 185, 963-972. [CrossRef]

100. Mitra, M.; Mishra, S. A Biorefinery from Nannochloropsis spp. Utilizing Wastewater Resources. In Application of Microalgae in Wastewater Treatment; Gupta, S.K., Bux, F., Eds.; Springer International Publishing: Cham, Switzerland, 2019; pp. 123-145, ISBN 978-3-030-13908-7.

101. Zhang, W.; Wang, F.; Gao, B.; Huang, L.; Zhang, C. An integrated biorefinery process: Stepwise extraction of fucoxanthin, eicosapentaenoic acid and chrysolaminarin from the same Phaeodactylum tricornutum biomass. Algal Res. 2018, 32, 193-200. [CrossRef]

102. Solomon, S.; Qin, D.; Manning, M.; Marquis, M.; Averyt, K.; Tignor, M.M.B.; Miller, H.L.; Chen, Z. Climate Change 2007: The Physical Science Basis: Contribution of Working Group I to the Fourth Assessment Report of the Intergovernmental Panel on Climate Change; Intergovernmental Panel on Climate Change, Ed.; Cambridge University Press: Cambridge, NY, USA, 2007; p. 996.

103. Yu, K.L.; Show, P.L.; Ong, H.C.; Ling, T.C.; Chen, W.-H.; Salleh, M.A.M. Biochar production from microalgae cultivation through pyrolysis as a sustainable carbon sequestration and biorefinery approach. Clean Technol. Environ. Policy 2018, 20, 2047-2055. [CrossRef]

104. Dong, T.; Knoshaug, E.P.; Davis, R.; Laurens, L.M.L.; Van Wychen, S.; Pienkos, P.T.; Nagle, N. Combined algal processing: A novel integrated biorefinery process to produce algal biofuels and bioproducts. Algal Res. 2016, 19, 316-323. [CrossRef]

105. Knoshaug, E.P.; Mohagheghi, A.; Nagle, N.J.; Stickel, J.J.; Dong, T.; Karp, E.M.; Kruger, J.S.; Brandner, D.G.; Manker, L.P.; Rorrer, N.A.; et al. Demonstration of parallel algal processing: Production of renewable diesel blendstock and a high-value chemical intermediate. Green Chem. 2018, 20, 457-468. [CrossRef] 